\title{
SEDIMENT YIELD ESTIMATION AND PRIORITIZATION OF WATERSHED USING REMOTE SENSING AND GIS
}

\author{
Sreenivasulu Vemu, Udaya Bhaskar Pinnamaneni \\ Department of Civil Engineering, JNT University, Kakinada, Andhra Pradesh, India-533003 \\ vemusree@gmail.com
}

Commission VIII/8: Land

KEYWORDS: Soil Erosion, USLE, Sediment yield, GIS, Remote sensing.

\begin{abstract}
:
Soil erosion is the greatest destroyer of land resources in Indravati catchment. It carries the highest amount of sediment compared to other catchment in India. This catchment spreading an area of 41,285 square $\mathrm{km}$ is drained by river Indravati, which is one of the northern tributaries of the river Godavari in its lower reach. In the present study, USLE is used to estimate sediment yield at the outlet of river Indravati catchment. Both magnitude and spatial distribution of potential soil erosion in the catchment is determined. From the model output predictions, it is found that average erosion rate predicted is $18.00 \mathrm{tons} / \mathrm{ha} /$ year and sediment yield at the out let of the catchment is 22.31 Million tons per year. The predicted sediment yield verified with the observed data. The Indravathi basin is divided into 424 sub-watersheds and prioritization of all 424 sub-watersheds is carried out according to soil loss intensity for soil conservation purpose. Generated soil loss map will be useful to soil conservationist and decision makers for watershed management. Overall $19.71 \%$ of the area is undergoing high erosion rates which are a major contributor to the sediment yield $(78.04 \%)$ in the catchment. This area represents high-priority area for management in order to reduce soil losses, which are mostly found in upstream of the catchment. It is indicated that the areas of high soil erosion can be accounted for in terms of steep unstable terrain, and the occurrence of highly erodible soils and low vegetation cover.
\end{abstract}

\section{INTRODUCTION}

Land degradation due to water erosion and deterioration of water quality by point source and non-point source are some of the main problems in most of the watersheds in India. In addition to losses of soil, many other problems are created by soil erosion: siltation of reservoirs, canals and rivers; deposition of unfertile material on cultivated lands; harmful effects on water-supply, fishing, power generation; and destruction of fertile agricultural land. According to Ministry of Irrigation in India, as much as 175 Mha i.e. $53 \%$ of geographical area is subjected to serious environmental degradation. Nearly $60 \%$ of the cultural area is suffering from the effects of erosion, taking the toll of the land at the rate of 5 to 7 Mha each year (Balakrishna, 1986). Study on global soil loss has indicated that soil loss rate in the U.S. is $16 \mathrm{t} / \mathrm{ha} / \mathrm{yr}$, in Europe it ranges between $10-20 \mathrm{t} / \mathrm{ha} / \mathrm{yr}$, while in Asia, Africa and South America, between 20 and 40 t/ha/yr (Pimentel et. al., 1993).

In assessing soil erosion, researchers always confront with the problem of selecting the appropriate model to use in a given area (Meijerink and Lieshout 1996). It is always important to adopt a suitable model that can be applied to the critical conditions of an area (Chisci and Morgan 1988). Some models are area-specific and may not perform well in other areas, since they are designed with a specific application in mind (Shrestha 2000). Therefore, selection of a proper model suitable for an area should be the first step in erosion modeling. Numerous soil erosion models have been developed over the past 50 years, globally. All the erosion models are developed by taking the existing models into consideration. In a few instances, many significant components of existing models are incorporated to new models. The new model may be adapted to fit other application or to take advantage of new technologies. In either case the refinement of older models and the formulation of new models rely on the foundational physical process of soil erosion and the historical development of modeling efforts.

The Universal Soil Loss Equation (USLE), in its original and modified forms, is the most widely used model to estimate soil loss from watersheds (Rao et al, 1994). That the various parameters of USLE can be derived from rainfall distribution, soil characteristics, topographic parameters, vegetative cover and information on conservation support (erosion control) practice are often available in the form of maps or can be mapped through collection of data from possible sources. Due to geographic nature of these factors USLE can easily be modeled into GIS (Jain 1994). The USLE model applications in the grid environment with GIS would allow us to analyze soil erosion in much more detail since the process has a spatially distributed character (Ashish Pandey et al. 2007). The GIS and Remote Sensing (RS) provide spatial input data to the model, while the Universal Soil Loss Equation (USLE) can be used to predict the sediment yield from the watershed.

In the present study, USLE is used to estimate potential soil erosion from Indravati catchment. Both magnitude and spatial distribution of potential soil erosion in the catchment is determined. An ArcGIS package is used in developing digital data and another GIS package Integrated Land and Water Information Systems (ILWIS) is used for processing remote sensing data. ILWIS is also used in spatial data analysis to determine magnitude and spatial distribution of potential soil erosion. 


\section{STUDY AREA}

The Indravati is one of the northern tributaries of the Godavari in its lower reach. The Indravati catchment lies between latitudes $18^{\circ} 27^{\prime} \mathrm{N}$ to $20^{\circ} 41^{\prime} \mathrm{N}$ and longitudes $80^{\circ} 05^{\prime} \mathrm{E}$ to $83^{\circ}$ $07^{\prime} \mathrm{E}$ (Figure 1). The river Indravati rises at an altitude of about 914 m near Thuamal Rampur village in the Kalahandi district of Orissa on the western slopes of the Eastern Ghats and joins Godavari at an altitude of about $125 \mathrm{~m}$. The main river flows for a length of about $477 \mathrm{Km}$. The Indravati basin with a catchment area of $41285 \mathrm{Km}^{2}$ constitutes $13.32 \%$ of the total Godavari basin. The basin has high hills, deep valleys and large plateaus. The mean annual rainfall in of this area is about 1288 $\mathrm{mm}$, most of which occurs between May and September. Average potential evaporation rates are $6.5 \mathrm{~mm}$ per day, while average minimum and maximum temperature are $13^{\circ} \mathrm{C}$ and 39 ${ }^{\circ} \mathrm{C}$ respectively. There are no major irrigation projects existing in the study area. The major land covers in the catchment are forest $(68 \%)$, followed by agriculture $(22 \%)$. Agriculture is the main occupation of the people in the area.

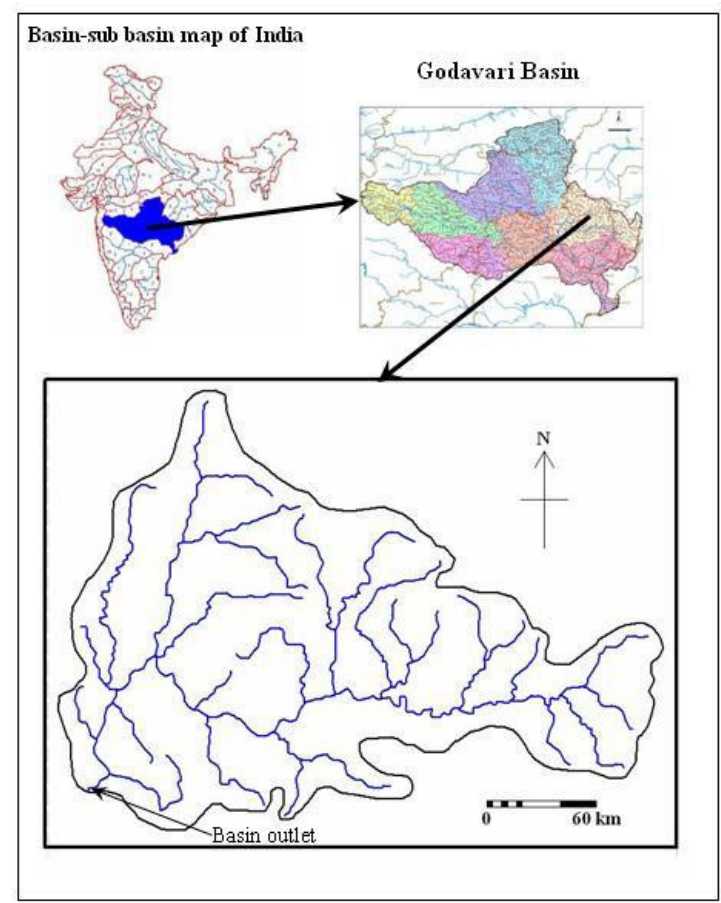

Figure 1. Location map of Indravati Catchment

\section{METHODOLOGY}

\subsection{Soil Erosion Model - USLE}

Techniques for prediction of soil loss have evolved over the years. The most widely used equation for soil loss prediction of the catchment is the Universal Soil Loss Equation (USLE). The USLE equation computes average annual soil loss (A) which is a product of five different factors that affect soil loss, and is given by:

$$
A=R K L S C P
$$

Where, $\mathrm{A}=$ average annual soil loss in tons per hectare, $\mathrm{R}=$ rainfall-runoff erosivity factor $(\mathrm{MJ} / \mathrm{ha} \cdot \mathrm{mm} / \mathrm{h}), \quad \mathrm{K}=$ soil erodibility factor (t.ha.h/ha/MJ/mm), LS = topographic or slope length/steepness factor, $\mathrm{C}=$ cover and cropping-management factor, $\mathrm{P}=$ supporting practices (land use) factor. All of the factors are dimensionless, with the exception of $\mathrm{R}$ and $\mathrm{K}$. The preparation of spatial data base for this model is explained below.

3.1.1 Rainfall Erosivity Factor (R): The erosivity factor $R$ is often determined from rainfall intensity if such data are available. In majority of cases rainfall intensity data are very rare, consequently attempts have been made to determine erosivity from daily rainfall data (Jain et al., 2001). In River Indravati catchment, no station has rainfall intensity data. Therefore $\mathrm{R}$ is determined using mean annual rainfall as recommended by Morgan and Davidson (1991). The expression is given below.

$$
\mathrm{R}=\mathrm{P} * 0.5
$$

Where, $\mathrm{P}=$ mean annual rainfall in $\mathrm{mm}$ and $\mathrm{R}=$ rainfall erosivity factor in $\mathrm{MJ} / \mathrm{ha} . \mathrm{mm} / \mathrm{h}$. A 20-year time series of monthly girded average precipitation dataset from the Climatic Research Unit -Average Climatology 2.0 (CRU-CL 2.0) (http://www.cru.uea.ac.uk/cru/data/tmc.htm) from 1982 to 2002 is used in preparing $\mathrm{R}$ factor layer. Inverse distance method, which is very fast and efficient weighted average interpolation method in ILWIS, is used to show spatial distribution of mean $\mathrm{R}$ factor values in Indravati catchment.

3.1.2 Soil Erodibility Factor (K): The soil erodibility factor $(\mathrm{K})$ represents both susceptibility of soil to erosion and the amount and rate of runoff, as measured under standard plot condition. In the study area no detailed soil map in the large scale is available. The soil map prepared by National Atlas and Thematic Mapping Organization, Department of Science and Technology, Government of India on 1: 2 Million scale is used to prepare $\mathrm{K}$ factor.

3.1.3 Slope length and steepness factor (LS): The topography affects the runoff characteristics and transport processes of sediment on a watershed scale. A $90 \mathrm{~m}$ resolution DEM from the Shuttle Radar Topography Mission (SRTM) is downloaded from ftp://e0mss21u.ecs.nasa.gov/srtm/, and gaps of no data is filled with coarser Gtopo 30 DEM (http://lpdaac.usgs.gov/gtopo30/hydro/index.asp).This rectified $90 \mathrm{~m}$ resolution DEM is used to prepare the LS factor as discussed below.

Slope Length Factor (L): Mc Cool et al. (1987) presented the following relationship to compute the slope length or $\mathrm{L}$ factor:

$$
\mathrm{L}=(\lambda / 22.1)^{\mathrm{m}}
$$

where $\mathrm{L}=$ slope length factor; $\lambda=$ field slope length $(\mathrm{m}) ; m=$ dimensionless exponent that depends on slope steepness, being 0.5 for slopes exceeding 5 percent, 0.4 for 4 percent slopes and 0.3 for slopes less than 3 percent. A grid size of $100 \mathrm{~m}$ is used as field slope length $(\lambda)$. Similar assumption of field slope 
length is made by several researchers (Onyando et al., 2005; Fistikoglu and Harmancioglu, 2002; Jain et al., 2001).

Slope Steepness Factor (S):For slope length longer than $4 \mathrm{~m}$, the slope steepness factor is derived using the following equations (McCool et al., 1987):

$\mathrm{S}=10.8 \sin \theta+0.03$ (for slope gradient $<9 \%$ )

$\mathrm{S}=16.8 \sin \theta-0.05$ (for slope gradient $\geq 9 \%$ )

where $S=$ slope steepness factor and $\theta=$ slope angle in degree. The slope steepness factor is dimensionless.

3.1.4 Cover (C) and Conservation practices (P) factors: The $\mathrm{C}$ factor is derived from NDVI distribution obtained from Landsat images downloaded (via http://edcsns17.cr.usgs.gov/EarthExplorer/) on internet. NDVI is positively correlated with the amount of green biomass, so it can be used to give an indication for differences in green vegetation coverage. NDVI-values are scaled to approximate C values using the following formula, developed by European Soil Bureau:

$$
\mathrm{C}=\mathrm{e}^{-\alpha(\operatorname{NDVI} /(\beta-\mathrm{NDVI}))}
$$

where; $\alpha, \beta$ are the parameters that determine the shape of the NDVI-C curve. An $\alpha$-value of 2 and a $\beta$-value of 1 are assigned to give the reasonable results (after Van der Knijff et al., 2000). $\mathrm{P}$ is the conservation practice factor, reflects the impact of support practices in the average annual erosion rate. It is the ratio of soil loss with contouring and/or strip cropping to that with straight row farming up-and-down slope. As there is only a very small area has conservation practices in the study area, $\mathrm{P}$ factor values are assumed as 1 for the basin

\subsection{Sediment Yield Estimation}

The ratio of sediment delivered at a given area in the stream system to the gross erosion is the sediment delivery ratio for that drainage area. Thus, the annual sediment yield of a watershed is defined as follows:

$$
\mathrm{SY}=(\mathrm{A})(\mathrm{SDR})
$$

Where, $\mathrm{A}=$ total gross erosion computed from USLE, $\mathrm{SDR}=$ sediment delivery ratio. A general equation for computing watershed delivery ratios is not yet available since they depend on several properties of the watershed like infiltration, roughness, vegetation cover, hydrograph or runoff drainage, etc. Since much of the above data are not available for the study area to derive SDR, some of the simple models given by different researchers have been tried to estimate sediment yield at the outlet of the basin, but the one given below by Williams and Berndt's (1972) is finally chosen because it gives reasonable results despite using few catchment characteristics.

$$
\mathrm{SDR}=0.627 \mathrm{SLP}^{0.403}
$$

Where, SLP = \% slope of main stream channel.

\subsection{Spatial Distribution of Soil Loss}

After completing data input procedure and preparation of the appropriate maps as data layers, they are analyzed in the GIS, to provide a estimate of the gross erosion map on $200 \mathrm{~m} \mathrm{X} 200$ $\mathrm{m}$ pixel size. Average soil loss is calculated as the product of each pixel value with pixel area then dividing with total area of the basin. The USLE model is applied for the following two scenarios.

\subsubsection{Estimation of Average Annual Soil Loss}

Average annual soil loss is estimated based on 20-year average rainfall erosivity factor and $\mathrm{K}, \mathrm{LS}, \mathrm{C}, \mathrm{P}$ factors.

\subsubsection{Prioritization of Sub-Watersheds}

The Indravathi basin is divided into 424 subwatersheds for prioritization purpose. Derived average annual soil loss layer is crossed with the sub-watershed map in a GIS environment to obtain soil loss in each sub-watershed. Average soil loss values in $\mathrm{t} / \mathrm{ha} / \mathrm{yr}$ for each sub-watershed are obtained by using aggregation option of ILWIS in table operation. Prioritization of sub-watershed has been done on the basis of average annual soil loss. Estimated values of sub-watershed wise soil loss are classified as follows (Table 1). P1 is the first priority category followed by P2, P3, P4, P5 and P6.

\begin{tabular}{|l|l|l|l|}
\hline Sr. No & Priority Class & Soil Loss (t/ha/yr) & Class \\
\hline 1 & P6 & $<5$ & Slight \\
\hline 2 & P5 & $5-10$ & Moderate \\
\hline 3 & P4 & $10-20$ & High \\
\hline 4 & P3 & $20-40$ & Very high \\
\hline 5 & P2 & $40-80$ & Severe \\
\hline 6 & P1 & $>80$ & Very severe \\
\hline
\end{tabular}

Table 1. Soil Loss Categories according to Average Annual Soil Loss

\section{RESULTS AND DISCUSSION}

The results obtained by analyzing the data are presented and discussed in this section. The average annual $\mathrm{R}$ factor values vary from 550 to $670 \mathrm{MJ} . \mathrm{mm} \mathrm{ha}^{-1} \mathrm{~h}^{-1}$ with a mean value of 602 MJ.mm ha ${ }^{-1} \mathrm{~h}^{-1}$ and a standard deviation is 25 . The $\mathrm{K}$ value in the study area varies from 0.6 to 0.8 . DEM of the study area revealed that $42 \%$ of area between altitude from $500 \mathrm{~m}$ to 700 $\mathrm{m}$. The combined spatial distribution of LS factor is derived using the DEM of the study area. LS factor values in the study area vary from 0.2 to 587 with a mean value of 4 . Areas with LS value between 0 and 4 cover $78 \%$ of the catchment area, and only $10 \%$ of the catchment has LS values greater than 11 . Spatial distribution of C factor was derived for the year 1998 and the $\mathrm{C}$ value in the study area varies from 0.1 to 0.3 .

After completing data input procedure and preparation of the appropriate maps as data layers, they were multiplied in the GIS, to provide a estimate of the gross erosion map on $200 \mathrm{~m} \mathrm{X}$ $200 \mathrm{~m}$ pixel size. Gross erosion map was reclassified (Figure 2) as per the guidelines suggested by Singh et al. (1992) for Indian conditions (Table 1). From the model output predictions ( Table 2) it is found that on average, 74.11 Million tons of soil are moved annually per year and average erosion rate predicted is 18 tons/ha/year. Sediment delivery ratio (SDR) for the catchment is found to be 0.3 using the empirical equation of Williams and Berndt. By multiplying the gross erosion with 
International Archives of the Photogrammetry, Remote Sensing and Spatial Information Sciences, Volume XXXIX-B8, 2012 XXII ISPRS Congress, 25 August - 01 September 2012, Melbourne, Australia

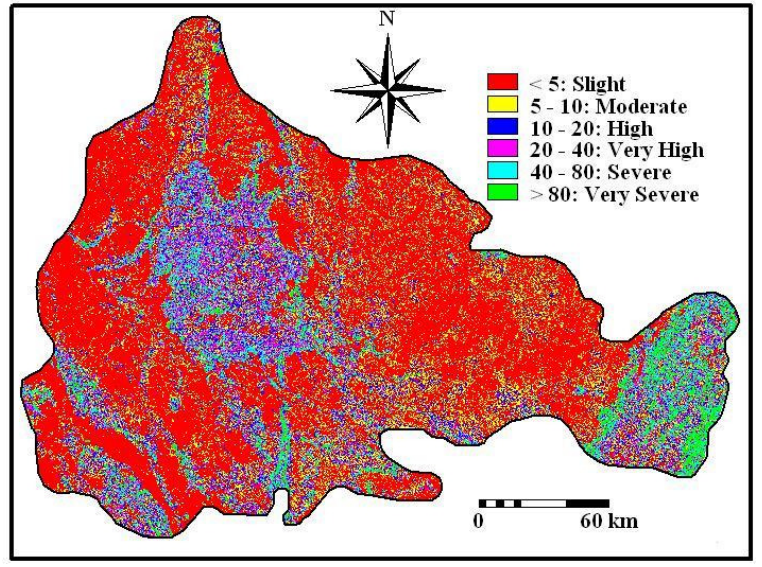

Figure 2. Spatial distribution of soil loss in Indravati catchment

\begin{tabular}{|c|c|c|c|c|c|}
\hline $\begin{array}{l}\text { Soil } \\
\text { loss } \\
(\mathrm{t} \\
\mathrm{ha}^{-1} \\
\left.\mathrm{y}^{-1}\right)\end{array}$ & $\begin{array}{l}\text { Erosion } \\
\text { risk } \\
\text { Classes }\end{array}$ & $\begin{array}{l}\text { Area } \\
\left(\mathrm{Km}^{2}\right)\end{array}$ & $\begin{array}{l}\text { Area } \\
(\%)\end{array}$ & $\begin{array}{l}\text { Soil } \\
\text { loss } \\
\text { (Million } \\
\text { tons) }\end{array}$ & $\begin{array}{l}\text { Soil } \\
\text { loss } \\
(\%)\end{array}$ \\
\hline$<5$ & Slight & 22400.88 & 54.26 & 5.79 & 7.81 \\
\hline $\begin{array}{l}5- \\
10\end{array}$ & Moderate & 6584.12 & 15.95 & 4.59 & 6.20 \\
\hline $\begin{array}{l}10- \\
20\end{array}$ & High & 4161.32 & 10.08 & 5.89 & 7.95 \\
\hline $\begin{array}{l}20- \\
40\end{array}$ & $\begin{array}{l}\text { Very } \\
\text { high }\end{array}$ & 3433.12 & 8.32 & 9.81 & 13.24 \\
\hline $\begin{array}{l}40- \\
80\end{array}$ & Severe & 2638.72 & 6.39 & 14.84 & 20.03 \\
\hline$>80$ & $\begin{array}{l}\text { Very } \\
\text { severe }\end{array}$ & 2066.76 & 5.01 & 33.17 & 44.77 \\
\hline Total & & 41284.84 & 100.00 & 74.11 & 100.00 \\
\hline
\end{tabular}

Table 2. Soil loss and erosion risk classes

SDR, sediment yield at the out let of the basin is found to be 22.3 Million tons per year. The observed average annual sediment yield at Pathagudem gauge site which is obtained from Central Water Commission (CWC), Government of India, at the out let of the basin support our results (Table 3). Almost

\begin{tabular}{|c|c|c|c|c|}
\hline $\begin{array}{c}\text { Station } \\
\text { Name \& } \\
\text { No. }\end{array}$ & Duration & Observed & Computed & \multirow{2}{*}{$\begin{array}{c}\text { Million tons } \\
\text { error }\end{array}$} \\
\cline { 3 - 4 } & & \multicolumn{2}{|c|}{} & \\
\hline $\begin{array}{c}\text { Pathagudem } \\
\text { (AGG00B5) }\end{array}$ & $\begin{array}{c}\text { Annual } \\
\text { average } \\
\text { (1992-2002) }\end{array}$ & 21.21 & 22.31 & +4.93 \\
\hline
\end{tabular}

Table 3. Computed and observed values (CWC, India) of sediment yield

half of the Indravati catchment $(54.26 \%)$ falls under slight erosion risk class where soil loss is lower than $5 \mathrm{t} \mathrm{h}^{-1} \mathrm{y}^{-1}$ (Table 2 ). Areas covered by moderate, high, very high, severe and very severe erosion potential zones are $15.95,10.08,8.32,6.39$ and 5.01 percent respectively (Table 2). Overall $19.71 \%$ of the area is undergoing high erosion rates which are a major contributor to the sediment yield (78.04\%) in the catchment. This area represents high-priority area for management in order to reduce soil losses, which are mostly found in upstream of the catchment.

Indravathi basin is divided into 424 sub-watersheds as shown in Figure 3. Soil loss for each sub-watershed is calculated.

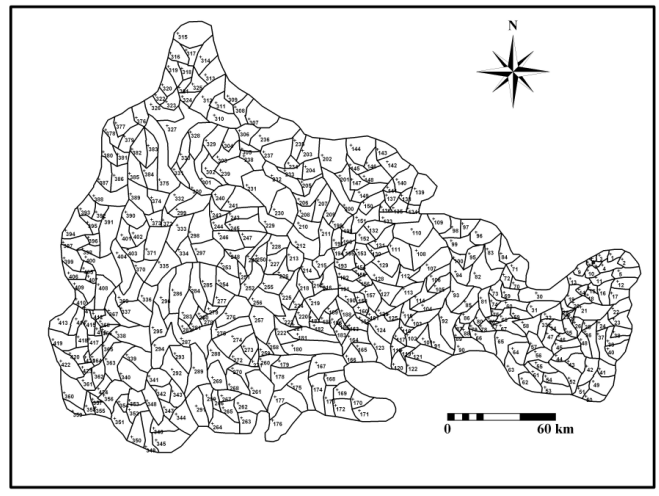

Figure 3. Sub-watershed of Indravati basin

Average annual soil loss for sub-watersheds in Indravathi basin varies from $1.93 \mathrm{t} / \mathrm{ha} / \mathrm{yr}$ to $167.29 \mathrm{t} / \mathrm{ha} / \mathrm{yr}$. As per the model prediction minimum soil loss occurs in sub-watershed number 407 and maximum soil loss occurs in sub-watershed number 41. Figure 4 shows distribution of the 424 sub-watersheds of

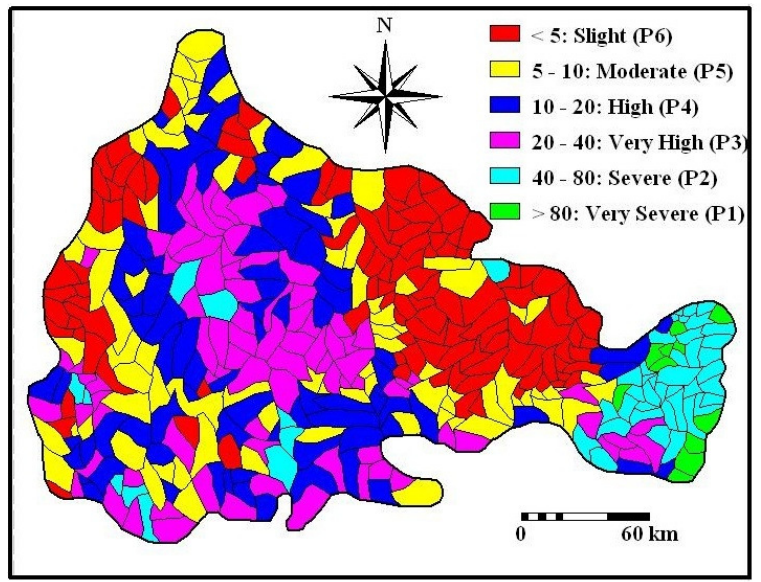

Figure 4. Prioritization Map of Different Sub-Watersheds in the Indravathi Basin

Indravathi basin according to soil loss intensity. From the analysis, it is observed that the number of watersheds falls in first priority zone (i.e., very severe erosion class; P1) is 11 . It is evident from analysis that the number of watersheds falls in P2, P3, P4, P5, P6 zones are 50, 85, 81, 82, and 115 respectively.

All sub-watersheds in first priority zone (P1) are found in upstream of the basin and the total soil loss from these subwatersheds is 7.45 million tons. Most of the sub-watersheds in second priority zone (P2) are also found in upstream of the basin and the total soil loss from these sub-watersheds is 18.87 million tons. Overall analysis indicates that though the percentage of total area under these two zones is 9.88 , but it contributes $35.52 \%$ of total soil loss in the basin. Therefore, it is essential to take conservation practices in these two zones. The 
area that falls under third priority zone (P3) is $20.52 \%$ and it contributes $30.88 \%$ of total soil loss. It is found that forth, fifth and sixth priority zones together contribute $69.59 \%$ of total area and soil loss from these three zones is $33.59 \%$ of total soil loss.

\section{CONCLUSION}

A quantitative assessment of soil loss is made using Universal Soil Loss Equation for Indravati catchment. All the thematic layers of R, K, LS and C are integrated to generate erosion risk map to find out spatial distribution of soil loss within the GIS environment. Since the USLE model does not take into account transportation and deposition, the actual sediment yield at the outlet is likely to be less than the estimated. Generated soil loss map is also able to indicate high erosion risk area which is useful to soil conservationist and decision makers. Prioritization of all 424 sub-watersheds in the Indravathi basin is carried out according to soil loss intensity for soil conservation purpose.

\section{References}

Ashish Pandey., Chowdary, V.M. and Mal, B.C., 2007. Identification of critical erosion prone areas in the small agricultural watershed using USLE, GIS and remote sensing, Water Resour Manage , 21, pp. 729-746.

Balakrishnan, P., 1986. Issues in water resources development and management $\&$ the role of remote sensing, Technical report of ISRO, India, No.ISRO-NNRMS- TR. pp.67-87

Chisci, G., and Morgan, R.P.C., 1988. Modelling soil erosion by water: Why and how, In: Morgan RPC, Rickson RJ (eds) Erosion assessment and modelling, Commission of the European communities report no. EUR 10860 EN, pp. 121-146

Fistikoglu, O., and Harmancioglu, N.B., 2002. Integration of GIS with USLE in assessment of soil erosion. Kluwer Academic Publishers. Water Resources Management 16, pp. $447-467$

Jain, S.K., 1994. Integration of GIS and remote sensing in soil erosion studies, Report No. CS(AR)-186, National Institute of Hydrology, Roorkee, India.

Jain, S.K., Kumar, S. andVarghese, J., 2001. Estimation of soil erosion for a Himalayanwatershed using GIS technique. Kluwer Academic Publishers. Water Resources Management 15, pp.41-54

McCool, D.K., Foster, G.R., Mutchler, C.K., and Meyer, L.D., 1987. Revised slope steepness factor for the universal Soil Loss Equation. Trans of ASAE 30(5), pp.1387-1396.

Meijerink, A.M.J., and Lieshout, A.M.V., 1996. Comparison of approaches for erosion modelling using flow accumulation with GIS. HydroGIS 235,pp. 437-444.

Morgan, R. P. C., and Davidson, D. A., 1991. Soil Erosion and Conservation, Longman Group, U.K.

Onyando, J.O., Kisoyan, P., and Chemelil, M.C., 2005. Estimation of Potential Soil Erosion for River Perkerra Catchment in Kenya. Water Resources Management 19, pp. 133-143
Pimentel David., 1993. World soil erosion and conservation (Edited), Cambridge University Press, U.K.

Rao, V.V., Chakravarty, A.K., and Sharma. U., 1994. Watershed prioritization based on sediment yield modeling and IRS-1A LISS data, Asian-pacific Remote Sensing Journal, 6(2), pp. 59-65

Shrestha, D.P., 2000. Aspects of erosion and sedimentation in the Nepalese Himalaya: Highland- Lowland relations. PhD thesis, Ghent University, Ghent

Singh, G., Babu, R., narain, P., Bhusan, L.S., and Abrol, I.P.,1992. Soil erosion rates in India. J Soil and water cons, 47(1). Pp. 97-99.

Williams, J.R., and Berndt, H.D., 1972. Sediment yield computed with universal equation. J Hydrol Div, ASCE 98(12), pp. 2087-2098.

Van der Knijff, J.M., Jones, R.J.A., and Montanarella, L., 2000 Soil erosion risk assessment in Italy, European Soil Bureau, EUR 19044 EN 